\title{
SECONDARY SCHOOL STUDENTS' PERCEPTION ACCORDING TO THEIR LEARNING STYLE OF A MATHEMATICS FLIPPED CLASSROOM
}

\author{
Vicent Fornons ${ }^{1}$ (D), Ramon Palau ${ }^{2}$, Raúl Santiago ${ }^{3}$ \\ ${ }^{1}$ Departament d'Educació de la Generalitat de Catalunya (Spain) \\ ${ }^{2}$ Universitat Rovira i Virgili, Facultat de Ciències de l'Educació i Psicologia, \\ Grup de Recerca ARGET (Spain) \\ ${ }^{3}$ Universidad de La Rioja (Spain) \\ vfornons@xtec.cat,ramon.palau@urv.cat,raulsantiagocampion@gmail.com
}

Received August 2020

Accepted January 2021

\section{Abstract}

The Flipped Classroom (FC) has been gaining prominence over the past few years. Many articles have shown that the FC increases the interaction between students and between the teacher and students, allowing different learning rhythms, facilitating access to materials, increasing collaboration between students and enhancing active learning. The present research looks at how students perceive the FC based on their learning style. The research was carried out with a sample consisting of two groups of third-year compulsory secondary education students (37 students in total) in the subject of mathematics. A quantitative methodology was used. At the beginning of the term, all students were given a questionnaire (CHAEA) to determine their learning style. At the end of term they were given a questionnaire (Driscoll) on their perception of the FC. The results show that students with a theoretical style of learning value the uses of the FC more positively and perceive greater interaction with peers and the teacher. However, students with a reflective learning style rate the FC lowest and have a the worse perception of the different key characteristics of the FC. In all statements, most students answered that they agree or very agree. These results are in line with those obtained by other authors in other contexts. This study brings certain nuances to the existing literature on the perception of the FC based on the students' learning style.

Keywords - Flipped Classroom, Mathematics, Learning style, Secondary education, Flipped learning.

\section{To cite this article:}

Fornons, V., Palau, R., \& Santiago, R. (2021). Secondary school students' perception according to their learning style of a mathematics Flipped Classroom. Journal of Technology and Science Education, 11(2), 227-244. https://doi.org/10.3926/jotse.1092

\section{Introduction}

\subsection{Flipped Classroom}

The Flipped Classroom (FC) or reverse classroom is a pedagogical model based on inverting the time spent and the role played by the students and teachers (Berenguer-Albaladejo, 2016). In the FC, instead of the theoretical concepts being presented in class by the teacher, the students usually watch online videos at home to become acquainted with the theory (Talbert, 2017). Therefore, when students arrive to the 
classroom, they have already received the content and the time spent in class can be used for higher-level activities, according to the Bloom Taxonomy (Bloom, Englehart, Furst \& Krathwohl, 1956), such as applying, analysing, evaluating or creating (Santiago \& Bergmann, 2018).

Likewise, this alternative use of time produces a second inversion, in this case in the roles played by the students and the teacher. Students go from being passive recipients in the traditional model, to active participants in the FC (Prieto, 2017). The teacher goes from being a mere transmitter of knowledge in the traditional classroom to a guide and creator of learning scenarios in the FC (Tourón \& Santiago, 2015).

Currently in the international databases Pubmed, Scopus, PsycINFO, Academic Search Complete, Education Research Complete and ERIC there are more than 5000 scientific papers on different areas and aspects of the FC (Strelan, Osborn \& Palmer, 2020). This highlights the impact that the FC is currently having on the world of education and how important it is for the future, as well as the interest it has aroused among teachers around the world at different educational stages and in different fields of knowledge.

\subsection{Learning Styles}

Learning styles in education are one of the most studied fields, but there is no universal definition of this concept (Hernández, 2010). Despite this, there is a consensus that it refers to the way each student learns (Coto, 2020). Authors such as Felder and Silverman (1988), Gardner (1983), Guild and Garger (1998), Honey (1988), Hunt (1978), Kolb (1976) and Lozano (2020), among others, have developed different typologies of learning styles and have created instruments to classify students according to their learning style. There are more than seventy different instruments for determining students' learning styles. Coffield, Moseley, Hall and Ecclestone (2004) state that there are thirteen instruments that are the most widely used in English: Allison and Hayes, Apter, Dunn and Dunn, Entwistle, Gregorc, Herrmann, Honey and Mumford, Jackson, Kolb, Myers-Briggs, Riding, Stenberg and Vermunt. However, the most widely used in the Spanish language is the Honey-Alonso Questionnaire on Learning Styles (CHAEA) (Gutiérrez \& García, 2011).

Alonso, Gallego and Honey (1997) describe the characteristics of the predominant learning styles, which are shown in Table 1.

\begin{tabular}{|l|l|}
\hline Learning style & \multicolumn{1}{|c|}{ Main features } \\
\hline Active Style & $\begin{array}{l}\text { Emphasis on specific experience. They are learners who engage fully and without prejudice } \\
\text { in new experiences. They are open-minded, confident and enthusiastic about new tasks. }\end{array}$ \\
\hline Reflective Style & $\begin{array}{l}\text { Emphasis on reflective observation. They are learners who like to consider experiences and } \\
\text { observe them from different perspectives. }\end{array}$ \\
\hline Theoretical Style & $\begin{array}{l}\text { Emphasis on abstract conceptualisation. They are learners who adapt and integrate } \\
\text { observations into logical and complex theories. They approach problems in a stepwise } \\
\text { vertical manner, in logical stages. }\end{array}$ \\
\hline Pragmatic Style & $\begin{array}{l}\text { Emphasis on active experimentation. Their strong point is the practical application of } \\
\text { ideas. They like to act quickly and confidently on ideas and projects that appeal to them. }\end{array}$ \\
\hline
\end{tabular}

Table 1. Characteristics according to learning style

Students are the basic source of information for assessing the quality, relevance and equity of their education, as well as the strengths and weaknesses of the learning process (Gorghiu, Anghel \& Ion, 2015) (Alemañy, Alemañy, Díaz \& Ramírez, 2014). This information draws on two sources: the students' learning outcomes and evaluations of their experiences during their education (Salas-Perea \& Salas-Mainegra, 2014).

The aim of this research is to analyse students' perceptions of the different key features of the FC as a function of each student's learning style. 
This research has the following hypotheses:

H1 - The student's learning style conditions his or her assessment of the FC.

H2 - Students with an active learning style value the FC more bighly.

\section{Theoretical Framework}

The FC began to become known in 2007, when two teachers, Jonathan Bergmann and Aaron Sams, chemistry teachers at Woodland Park High Scholl in Colorado, videotaped PowerPoint presentations of their classes and posted them on the internet for students who were unable to attend class. To their surprise, their videos went viral and many students started watching them (Bergmann \& Sams, 2012). Another milestone that helped popularise the FC was the appearance of the Khan Academy website, founded by Salman Khan in 2006, which has videos of classes for different subjects (Parslow, 2005).

Since then, there have been many studies on the FC for mathematics that have concluded that using this model means that more time can be spent in the classroom on methodological strategies based on active learning (Amstelveen, 2018; Fung, 2020; Gordijn, Oosterhout \& Dijkstra, 2017; Heuett, 2017; Karampa \& Paraskeva, 2018; Khan \& Watson, 2018; Song \& Kapur, 2017; Steen-Utheim \& Foldness, 2018), which results in increased student engagement (Belmonte, Cabrera, Núñez \& Sánchez, 2019; Clarck \& Kaw, 2019; Hodgson, Cunningham, McGee, Kinne \& Murphy, 2017; Jordán, Magreñán \& Orcos, 2019; Nihlawi, El-Baz \& Gunn, 2017). Students can also set their own learning pace (Esperanza, Fabian \& Toto, 2016; Sun, Xie \& Anderman, 2017; Toor \& Mgombelo, 2018) and take responsibility for it (Lopes \& Soares, 2017; Triantafyllou \& Timcenko, 2014; Ziegelmeier \& Topaz, 2015).

Increased interaction between students, and between students and the teacher, has also been found (Fredriksen, Hadjerrouit, Monaghan \& Rensaa, 2018; Karampa \& Paraskeva, 2018; Novak, Kensington-Miller \& Evan, 2016; Steen-Utheim \& Foldness, 2018; Sun et al, 2017), leading to increased collaboration among students and an improved classroom work environment (Clark \& Kaw, 2019; Guerrero, Beal, Lamb, Sonderegger \& Baumgartel, 2015; Heuett, 2017; Jordán et al., 2019; Sánchez-Compaña \& Sánchez-Cruzado, 2019).

However, some studies, such as Li, Zheng and Yang (2017), conclude that there is no significant effect on student satisfaction and attitudes in cooperative learning. Leatherman and Cleveland (2018) found that among students dissatisfied with the FC, $18 \%$ were dissatisfied with active learning activities. Talbert (2012) points out that the flipped classroom environment can be a culture shock for students and result in students not taking responsibility for their learning.

Most research has found that the students' academic performance increases when the FC is used instead of the traditional classroom in the area of compulsory secondary school mathematics. This increase is evidenced in works such as Belmonte et al. (2019); Chen, Yang and Hsiao (2015); Esperanza et al. (2016); Hung, Sun and Liu (2018); Kumar, Chang and Chang (2015); Ni, Kwok, Zhen, Xie, Long, Zheng et al. (2015); Song and Kapur (2017); Stroh and Sink (2002) and Wei, Cheng, Chen, Yang, Liu, Dong et al. (2020). However, the work of Kirvan, Rakes and Zamora (2015) could not demonstrate the increase because the results were similar in both groups.

There have been many attempts by researchers to define learning styles (Hernández, 2010). In the 1940s, researchers focused on cognitive elements or psychological aspects (Rayner \& Riding, 1997). Later on, a third trend appeared that proposed the synthesis of the two approaches, arguing that learning style is constituted by cognitive style and learning strategies (Alonso et al., 1997). Dunn and Dunn (1978) indicated that motivation, emotions and sociological aspects are variables that influence learning styles. In the 1980s, with the increase in research on learning styles, the affective dimension began to be incorporated (Hervás \& Hernández, 2004). In the 1990s, Rayner and Riding (1997), researched the relationship not only of cognitive style with learning strategies but also with the affective dimension and motivational aspects. Since Goleman defined emotional intelligence (Goleman, 1998), there has been a resurgence of interest in including emotional aspects in order for studies to go deeper into the theory of 
learning styles. Gallego (2004) analysed different instruments and tools for diagnosing learning styles and only found six that analyse cognitive and affective styles together. The CHAEA is one of these, and classifies students into four learning styles (Table 1).

A study carried out by Padierna-Luna, Oseguera-Rodríguez and Gudiño-Hernández (2009) using the CHAEA questionnaire with a sample of 174 students, indicated that learning styles are not associated with age or gender. On the other hand, Castillo, Bracamonte, De la Rosa, Sandoval and Morales (2009) with a sample of 651 students found that learning styles are heterogeneous depending on the university course.

In the field of education, learning styles have become important, as students' can be classified easily according to their learning styles (Coffield et al., 2004). Moreover, proponents of learning style assessment argue that optimal instruction requires diagnosing individuals' learning styles and adapting learning activities accordingly (Pashler, Mcdaniel, Rohrer \& Bjork, 2008). In contrast, Riener and Willingham (2010) claim that, under controlled conditions, learning is equivalent regardless of whether students are learning according to their learning style or not. Other authors, such as Busch and Watson (2019) and Westby (2019) directly deny the existence of learning styles and their influence.

Other research aims to determine the relationship between students' learning styles and the use of the FC. For example, Kim (2018) examined the relationships between university students' learning styles (Kolb questionnaire), personality traits (Big Five Personality Test) and satisfaction with the technique (personal interviews). Likewise, Jalil, Kassim and Madar (2019) compared students' academic outcomes when using the FC and their learning style.

The present research contributes to extending the existing knowledge and literature on the relationship between learning styles and the FC.

\section{Research Methodology}

A quantitative approach was used in this research, as data were collected to determine the students' behaviour and perceptions. The scope of the research is correlational, as it aims to ascertain the relationship between students' learning styles and their perception of the FC.

The research participants were two groups of 3rd year Compulsory Secondary Education (14- and 15-year-old), called ESO in the Spanish and Catalan languages, students from the Ermengol IV Secondary School in the town of Bellcaire d'Urgell in Spain. The 3rd ESO A class had 19 students and the 3rd ESO $\mathrm{B}$ class had 18 students. The components of the classes did not vary during the research. They had already been created at the beginning of the research and were homogeneous. The students used the FC throughout the first term of the school year in the mathematics classes.

Two questionnaires were applied. The Honey-Alonso Questionnaire of Learning Styles (CHAEA), which consists of 80 questions (20 items for each of the four learning styles) with two possible responses, either agree or disagree. The maximum score for each style (Active, Reflective, Theoretical and Pragmatic) is 20.

In 1988, Peter Honey and Alan Mumford created a learning styles questionnaire called LSQ (Learning Styles Questionnaire) to determine why in a situation where two people share a text and a context one person learns while the other does not. They concluded that there are four learning styles, corresponding to the four phases of a cyclical learning process: Active, Reflective, Theoretical and Pragmatic. In Spain, these results were collected by Catalina Alonso in 1992, who translated and adapted the LSQ questionnaire into Spanish, renaming it CHAEA (Honey-Alonso Questionnaire on Learning Styles) (Alonso et al., 1997).

The CHAEA questionnaire has been used on many occasions to determine students' learning styles when the FC is used. Canizales, Ries and Rodríguez (2020) used the CHAEA questionnaire in a previous phase of a research action in a university sports education classroom to diagnose the predominant situations in the classroom before using the FC. Martin and Santiago (2017) describe using the CHAEA questionnaire 
within the activities carried out in a FC experience with secondary school students in the learning consolidation phase. Rivero (2019) evaluates three models, including the FC, for teaching the subject of general botany in agricultural engineering, and at the beginning of the research he uses the CHAEA questionnaire to determine the students' styles. Coa (2018) uses the CHAEA questionnaire with students of basic mathematics in the health sciences degree course to relate their academic results with their learning style when the FC is used. The CHAEA questionnaire has an acceptable internal consistency, as well as adequate measurement stability over time (Juárez, 2014), and also shows high reliability indices and construct validity (Maureira, 2013).

On the other hand, the FC perception questionnaire was designed by Thomas Driscoll (2012) and adapted and translated with the author's permission (Martín \& Santiago, 2015). It is a questionnaire consisting of 12 questions with a Likert-type scale, in which students have the following response options: "Strongly Agree" - "Agree" - "Neither Agree nor Disagree" - "Disagree" - "Strongly Disagree". In addition, it contains six multiple-choice questions on the type of devices used, the length of the videos, and the time spent on flipped tasks. Finally, there are three open-ended questions in which students can comment on what they liked most about the flipped classes, what they would recommend to improve the flipped classes and anything else they would like to say about the classes.

At the beginning of the term, all students completed the CHAEA questionnaire to determine their learning style. At the end of the term, after having used the FC, they answered the FC perception questionnaire. During the term, three topics from different blocks of the subject of mathematics were covered. Topic 1: Fractions, from the numeration and calculation block; Topic 2: Geometric places, from the space and shapes block; and Topic 3: Polynomials, from the changes and relations block, as shown in Figure 1.

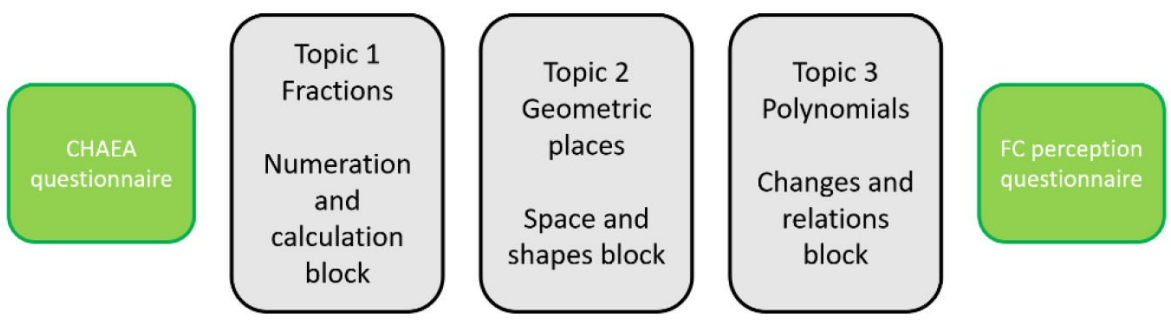

Figure 1. Distribution of instruments during the term

The data were obtained from the students' responses to an online Google Form with the questions from the questionnaires mentioned above. Once the data had been collected, they were analysed using an Excel spreadsheet. For the analysis, students were first categorised according to their learning style based on their responses to the CHAEA questionnaire. Then, the results of the FC perception questionnaire were analysed for each style.

The material and method used by the research participants were as follows: the mathematics lessons with the FC always followed the same process in both groups and were taught by the same teacher. Before each class, the students had to watch a video at home of no more than 10 minutes, made by the teacher and with content from the subject. The videos were available on the class Moodle and were published on the Edpuzzle page, which meant that the videos contained questions and could not be advanced.

Once in class, the students asked questions they had about the content in the video seen at home. Once the possible doubts had been resolved, the students were placed in groups of four students (the group members changed for each new topic) and they carried out activities related to the content seen at home. At the end of an activity, a volunteer presented his or her solution on the blackboard and the teacher corrected and commented on it for all the students, as shown in Figure 2. 


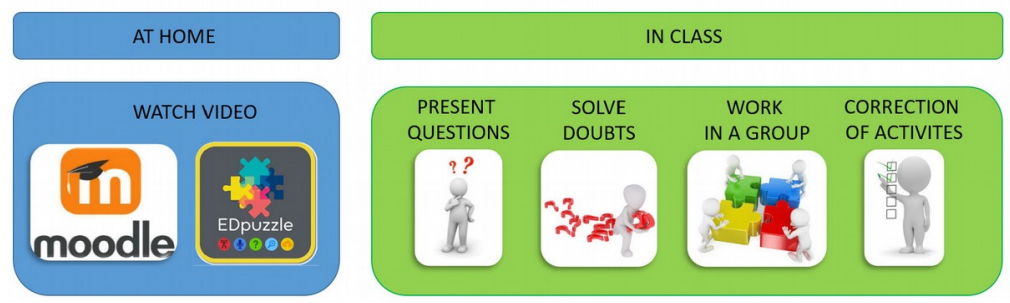

Figure 2. Process followed for mathematics lessons in the FC

\section{Results}

The percentages obtained by the students according to their learning style to the main questions of the questionnaire designed by Thomas Driscoll (2012), and adapted and translated to Spanish (Martín \& Santiago, 2015), are shown below. These percentages were obtained by first dividing the students into the four styles based on their answers to the CHAEA questionnaire. All 37 students answered the questionnaires, of which $62 \%$ were girls and $38 \%$ were boys.

As can be seen in Figure 3, students with a theoretical style are those who perceive that their interactions with the teacher during class are more frequent and positive. On the other hand, students with a reflective style have the lowest perception of this.

Figure 4 shows that students with a theoretical style are the ones who value most positively their interactions with classmates. On the other hand, those with a reflective style rate this aspect the lowest.

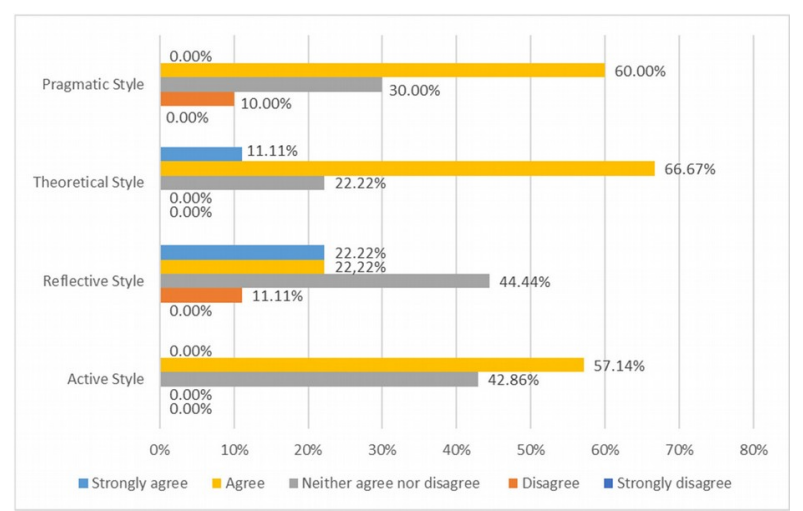

Figure 3. My interactions with the teacher during class are more frequent and positive

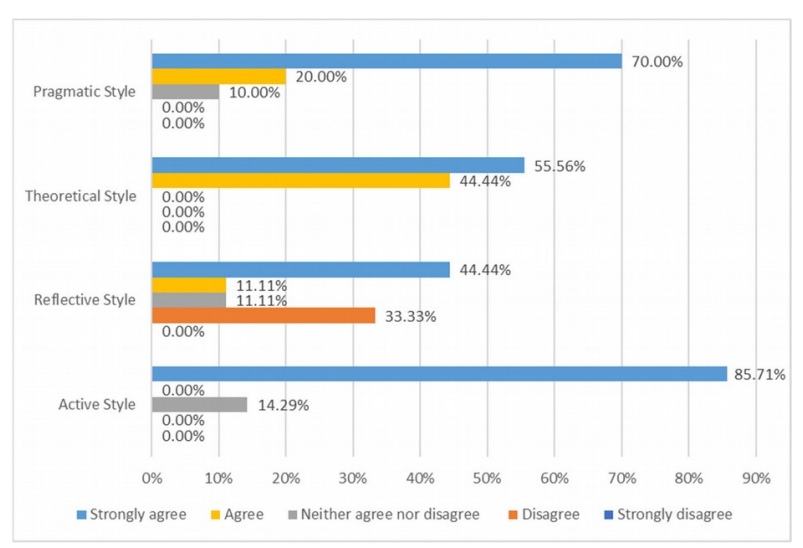

Figure 4. My interactions with my classmates during class are more frequent and positive 
Figure 5 shows that students with a pragmatic style rate the access to learning materials and content most positively and those with a reflective style rate it most negatively.

Figure 6 shows that students with a pragmatic style are the ones who rate highest the possibility of choosing the type of materials that best fit their way of learning, and those with an active style are the ones who rate it lowest.

All students in the active style "agree" or "strongly agree" that the FC allows them to learn at their own pace (Figure 7), whereas students with the theoretical learning style give the lowest rating of this.

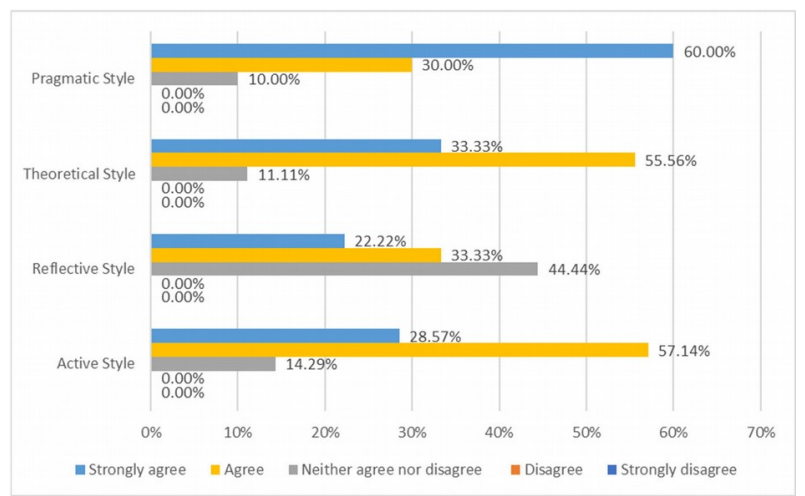

Figure 5. I have better access to learning materials and content

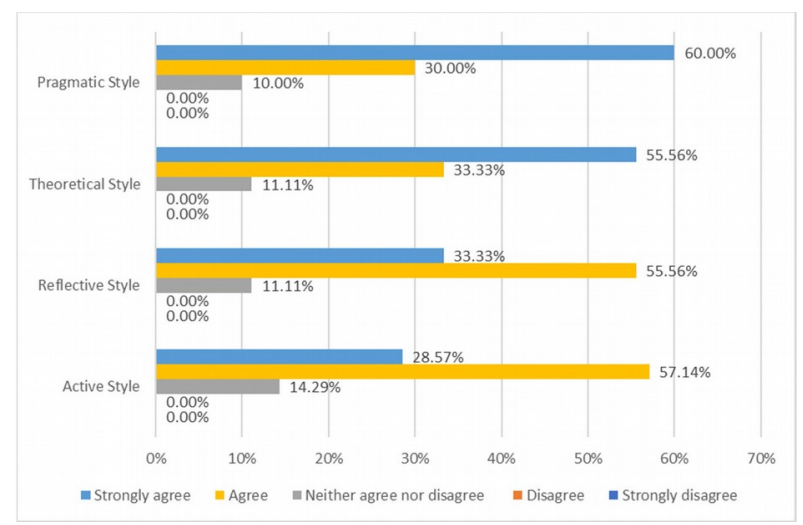

Figure 6. I can choose the type of materials that best suit my way of learning

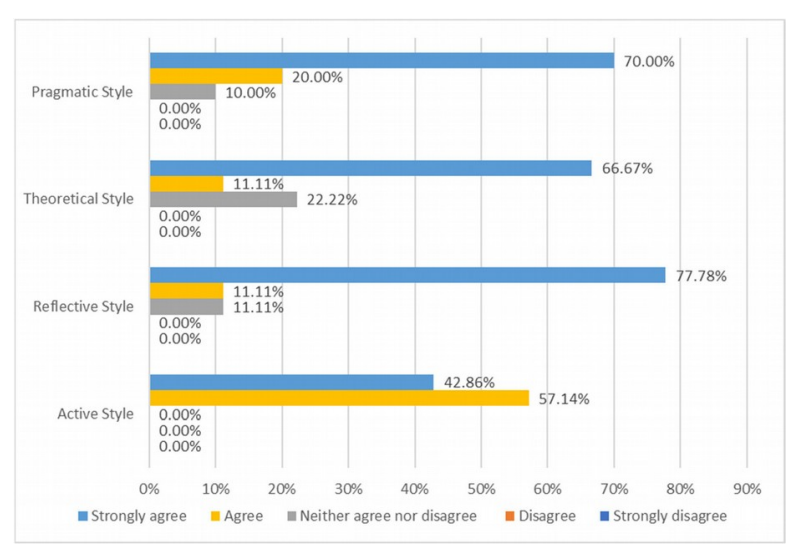

Figure 7. I can learn at my own pace

Students with a theoretical style agree the most that the FC allows them to show what they have learned in different ways (Figure 8); however, the students with a reflective style rated this the lowest. 
Figure 9 shows that the students who agree the most that they are more able to collaborate with their classmates are those with an active learning style. On this occasion, students with a reflective style are the ones who agree the least with the statement. It is also worth noting that no students from the active or pragmatic styles disagree or strongly disagree, and only $11.11 \%$ of the students from the reflective and theoretical styles neither agree nor disagree with the statement, thus showing that the perception that the FC allows more collaboration with other classmates is unanimous across all learning styles.

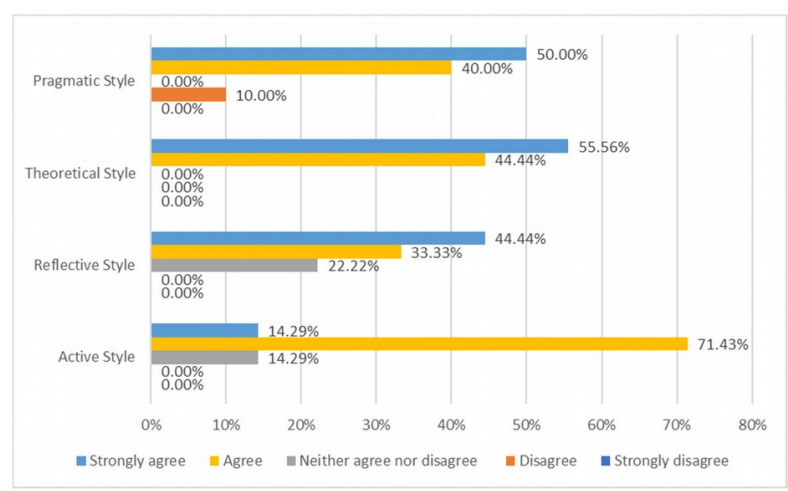

Figure 8. I can show what I have learned in a variety of ways

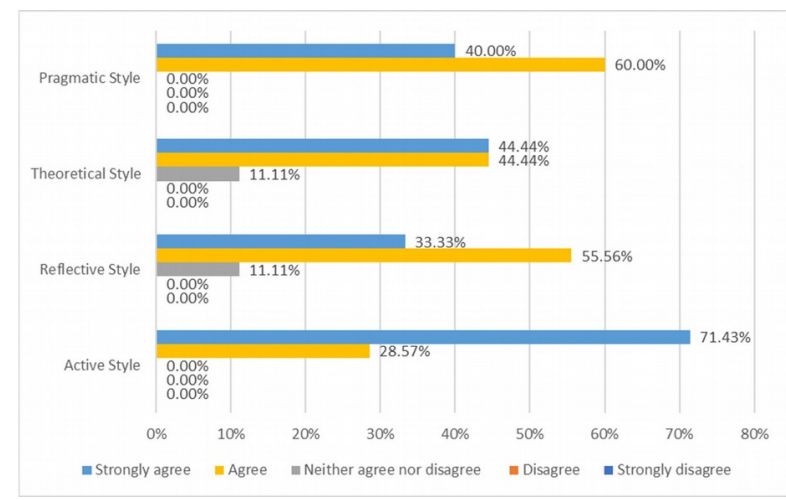

Figure 9. I am more likely to collaborate with my classmates

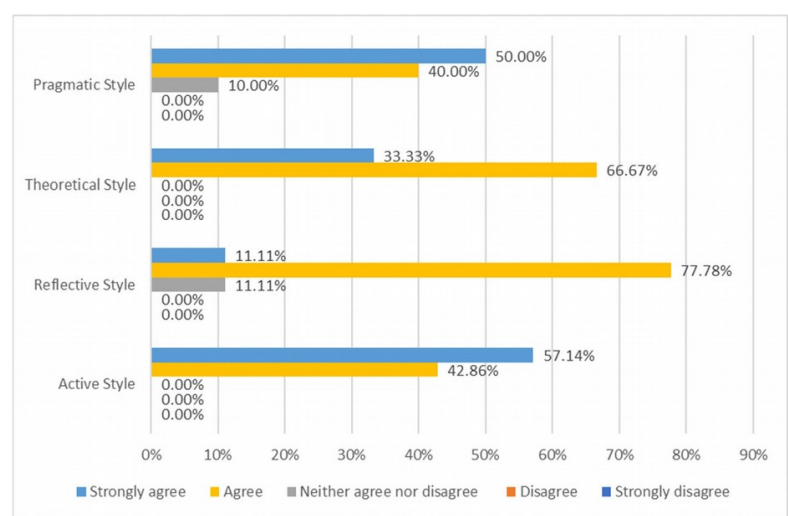

Figure 10. I am more able to make decisions about how to learn

$100 \%$ of the active and theoretical learning style students "agree" or "strongly agree" that using the FC gives them the possibility to make decisions about the way they learn (Figure 10). A total of 88.99\% of 
the reflective learning style and $90 \%$ of the pragmatic style "agree" or "strongly agree", and the rest "neither agree nor disagree".

Students with a reflective learning style are the ones who agree the most that the FC allows them to work more on critical thinking (Figure 11), and those with a pragmatic style are the ones who perceive it the least.

$100 \%$ of the students with the active and pragmatic styles "agree" or "strongly agree" that FC enables active learning (Figure 12). Students with a reflective style have the lowest percentage of "strongly agree" with the statement.

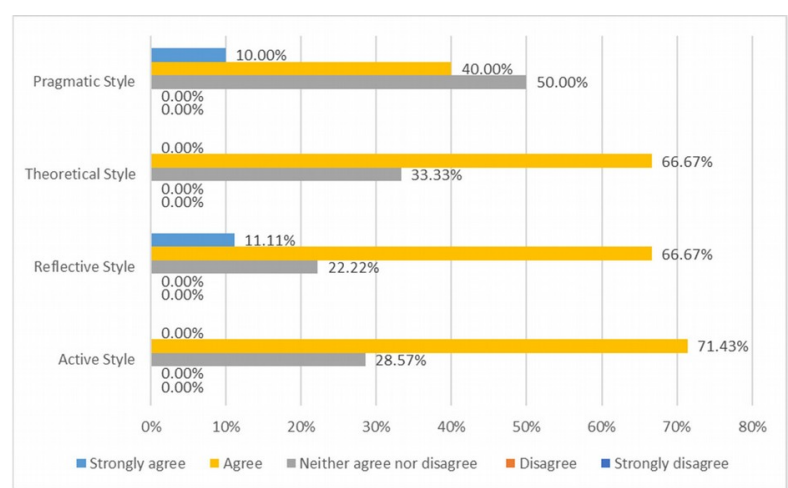

Figure 11. In class we work more on critical thinking

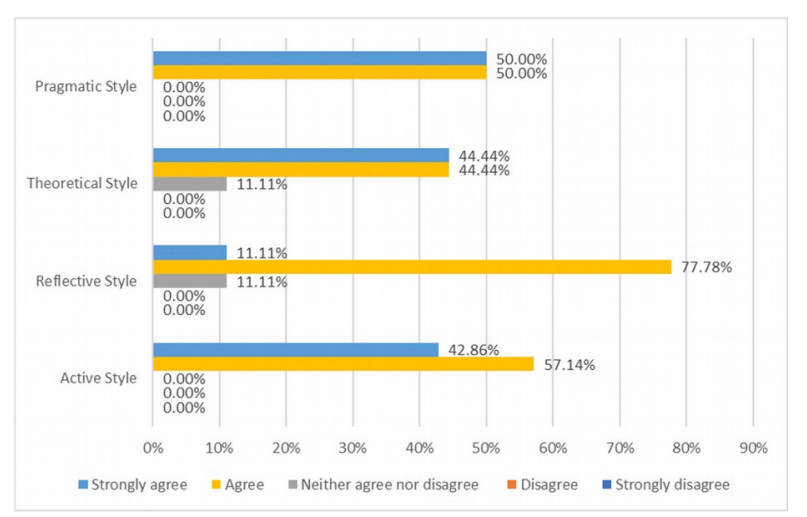

Figure 12. Learning is more active and experiential

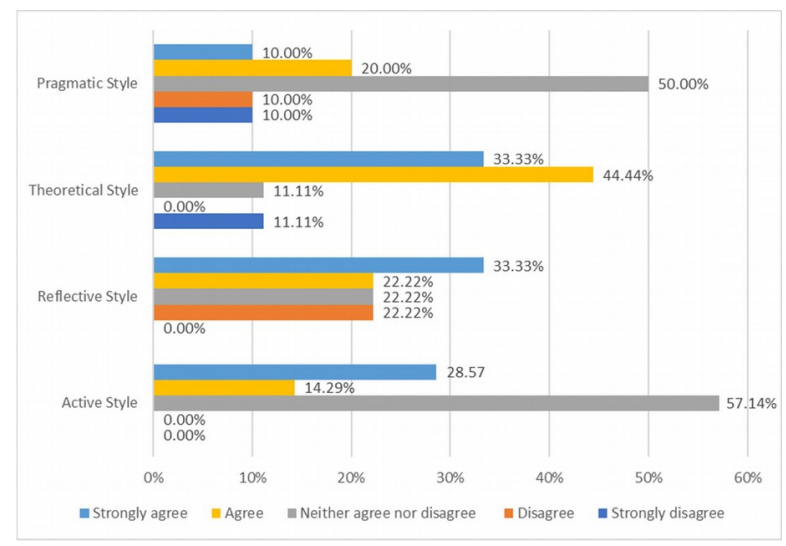

Figure 13. My teacher takes into account my strengths, weaknesses and interests 
Students with an active style agree the most with the statement that with the FC the teacher takes into account their strengths, weaknesses and interests (Figure 13). Those who least agree with this statement are the pragmatic style students, as 10\% respectively "strongly disagree" and "disagree".

The students with a theoretical style agree most with the statement that with the FC the teacher can get to know the students better (Figure 14). The students with a pragmatic style agree the least.

In relation to the time spent on homework or "flipped" tasks (Figure 15), 57.15\% of active style students and $55.55 \%$ of reflective style students answered "considerably less than in other subjects" and "somewhat less than in other subjects". A total of $60 \%$ of students with a pragmatic style responded "somewhat less than other subjects". Finally, 55.56\% of students with a theoretical style said "the same as other subjects". This shows that, in general, the students do not generally spend more time using the FC.

Students were also asked to rate the experience of using the FC from 1 to 10 (Figure 16). The average of the responses of students with an active style was 8.14, for students with a reflective style it was 7.56, for students with a theoretical style it was 8.56 and for students with a pragmatic style it was 7.78.

The distribution of learning styles was fairly balanced (Figure 17), with no one style standing out from the others. However, it can be seen that the pragmatic style, with $28.57 \%$ of students, is the predominant style in the sample in which the research was carried out. In second place are the theoretical and reflective styles, both with $25.71 \%$ of the students. And in last place, more than 8 points behind the first, is the active style with $20 \%$.

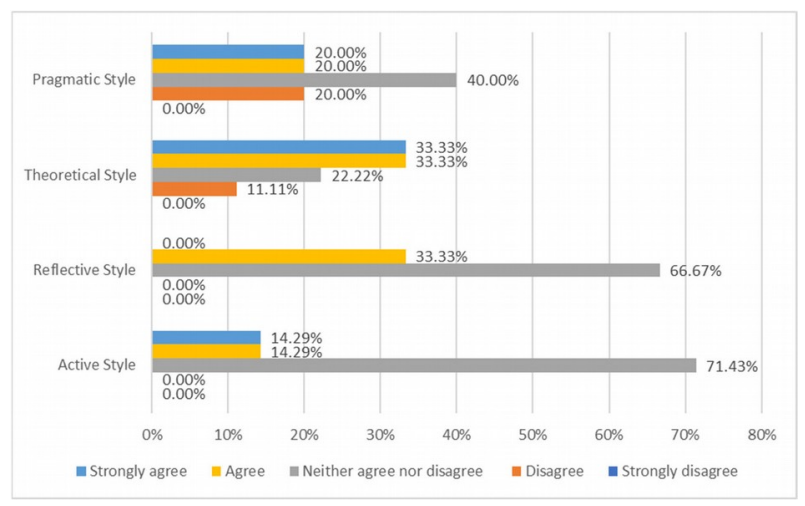

Figure 14. I think that with the Flipped Classroom my teacher can get to know me better

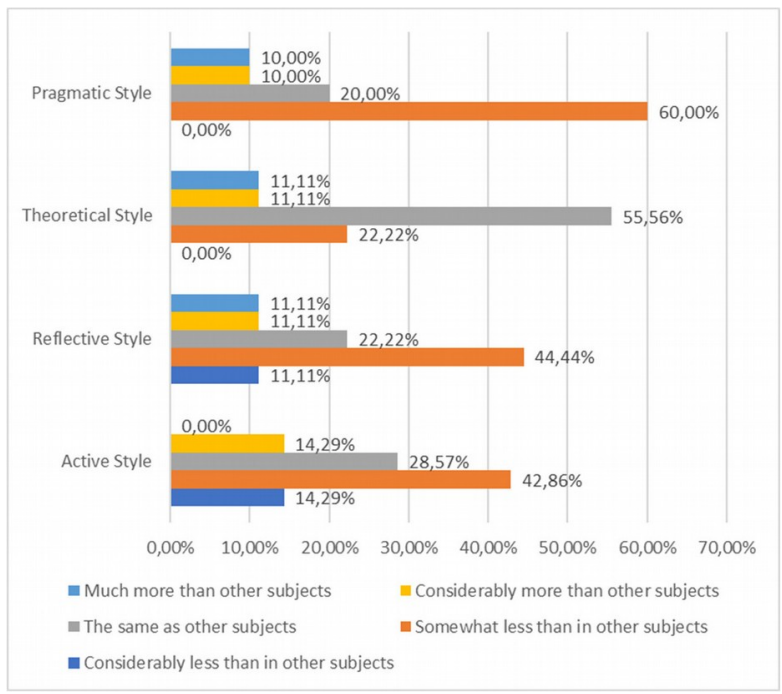

Figure 15. How much time do you spend on flipped homework? 


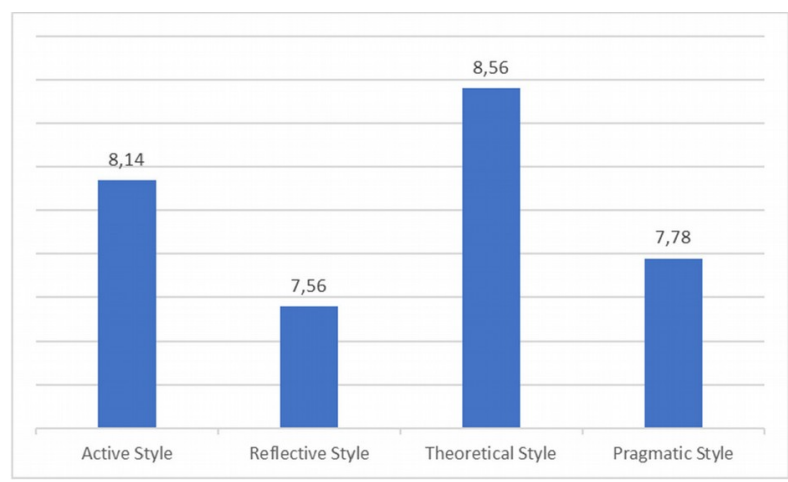

Figure 16. How would you rate the Flipped Classroom experience from 1 to 10 ?

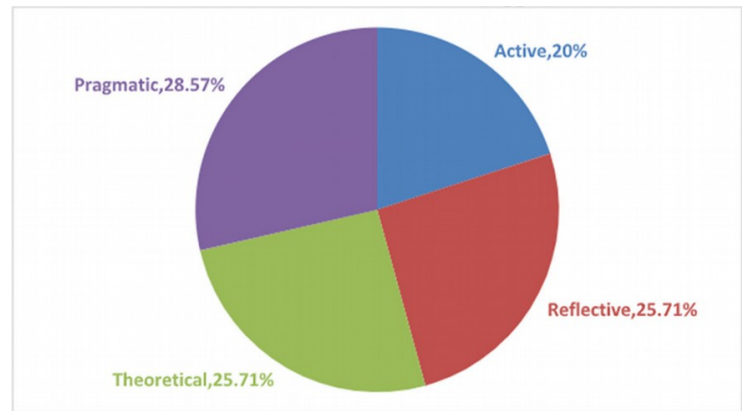

Figure 17. Distribution of learning styles

\section{Discussion}

The students in this sample perceive their interactions with the teacher and peers during class to be more frequent and positive. These results are in line with those obtained by Fredriksen et al. (2018), Karampa and Paraskeva (2018), Novak et al. (2016), Steen-Utheim and Foldnes (2018) and Sun et al. (2017).

Amstelveen (2018), Fung (2020), Karampa and Paraskeva (2018), Khan and Watson (2018) and Steen-Utheim and Foldnes (2018) find that the use of the FC allows more time to carry out methodological strategies that facilitate active learning, this is consistent with the perception obtained from students who agree that with the FC learning is more active and experiential.

The results also show that the students in this sample agree that they can learn at their own pace and are more likely to make decisions about how they learn. These statements are consistent with those made by Esperanza et al. (2016), Sun et al. (2017) and Toor and Mgombelo (2018) who state that students using the FC can set their own learning pace.

The results obtained are in line with the research carried out by Driscoll (2012) using the questionnaire he designed. He showed that $80 \%$ of students who used the FC had more consistent and positive interactions with the teacher and peers during lessons, were able to work at their own pace, had more access to material and instruction, were able to use more options to demonstrate learning and saw learning as a more active process. In addition, $70 \%$ of students responded that they were more likely to have choices in what learning tasks to use, more likely to engage in collaborative decision-making with other students, and more likely to work on critical thinking.

Around $80 \%$ of the students in this research report that they spend the same or less time on flipped homework compared to other subjects. This perception contradicts the findings of research by Muir (2020) and Weinhandl, Lavicza, Hohenwarter and Schallert (2020), with secondary school students and in mathematics classes, who found that using the FC requires more effort from students. 


\section{Conclusion}

The aim of this research was to analyse the students' perception of the different key features of the FC depending on the learning style of each student.

The following hypotheses were proposed:

\section{H1 - The learning style of the learner conditions his or her assessment of the FC.}

In view of the results and their analysis, we can conclude that the students' assessment of the different aspects of the FC in this research varied depending on their learning style, thus validating the first hypothesis of the study.

Thus, students with a theoretical learning style agree that their interactions with the teacher during class are more frequent and positive, that their interactions with peers during class are more frequent and positive, that they can show what they have learnt in different ways and that the teacher can get to know them better; However, they do not agree so much that they can learn at their own pace when using the FC.

Likewise, those with an active style are the ones who agree the most that by using the FC they can learn at their own pace, they have more possibilities to collaborate with other classmates, they have more possibilities to make decisions about the way they learn and that the teacher takes into account their strengths, weaknesses and interests. However, they are least likely to agree that they have the possibility to choose the type of materials that best suit their way of learning.

Students with a pragmatic style emphasise that by using the FC they have better access to learning materials and content, they have the possibility of choosing the type of materials that best suit their way of learning and that learning is more active and experimental. However, they do not believe that the teacher takes into account their strengths, weaknesses and interests, that he/she can get to know them better or that critical thinking is more developed in class.

Finally, those with a reflective style only stand out in the assessment that the FC allows them to work more on critical thinking in class. However, they disagree that their interactions with the teacher during class are more frequent and positive and that their interactions with classmates during class are more frequent and positive.

\section{H2 - Students with an active learning style value the FC more bighly.}

From the results obtained, we can conclude that the theoretical style students in this research are those who value the use of the FC most positively, followed by the active style students, then the pragmatic style students and finally the reflective style students. Therefore, the second research hypothesis has not been verified, as the theoretical style students were the ones who rated the FC highest.

If the results obtained are confirmed in future research, they could help teachers to gain a better idea of how their students will value the use of FC depending on their learning style. This would help teachers to make the decision whether to use the FC with a certain group of students, or, if they are already using it, how to plan the FC lessons. For example, if the class is dominated by students with an active learning style the teacher could plan more group work in the extra time that using the FC allows in class. If the class is dominated by pragmatic learners, the teacher might want to do tasks that encourage active and experiential learning.

Moreover, these results could also help school principals who want to invest in the use of new didactic models. The results provide more decision elements depending on the predominant learning style of the students. They show the acceptability and appropriateness of using the FC depending on the predominant learning style of the students in the school. This information could be applied if, for example, a school principal would like to propose to the school staff to implement the FC in a certain educational cycle. In view of the results obtained, the most suitable class would be the one with more students with a 
theoretical style and the least recommendable class would be the one with more students with a reflective style.

The research has limitations related to the sample size, since the 3rd year ESO A class had 19 students and the 3rd year ESO B class had 18 students. The time in which the students were using the FC, one term, is another limitation. For these reasons, the above conclusions cannot be generalised, especially because a representative sample was not used. It would be interesting in the future to replicate the research with a larger number of students and for a longer period.

In addition, in future research related to learning styles and the use of the FC, students' academic results could be analysed in addition to their perceptions of the technique. The analysis of the results would provide further data that could be used for deciding the appropriateness of implementing the FC, taking into consideration the predominant learning style among students.

\section{Declaration of Conflicting Interests}

The authors declared no potential conflicts of interest with respect to the research, authorship, and/or publication of this article.

\section{Funding}

The authors received no financial support for the research, authorship, and/or publication of this article.

\section{References}

Alemañy, E., Alemañy, C., Díaz, P., \& Ramírez, H. (2014). Percepción de estudiantes sobre el proceso docente educativo Students' perception about educative process. Revista Habanera de Ciencias Médicas, 13(6), 960-972.

Alonso, C., Gallego, D., \& Honey, P. (1997). Los estilos de aprendiraje. Procedimientos de diagnóstico y mejora ( $7^{\text {th }}$ ed.). Bilbao: Mensajero.

Amstelveen, R. (2018). Flipping a college mathematics classroom: An action research project. Education and Information Technologies, 24(2), 1337-1350. https://doi.org/10.1007/s10639-018-9834-z

Belmonte, J.L., Cabrera, A.F., Núñez, J.A.L., \& Sánchez, S.P. (2019). Formative transcendence of flipped learning in mathematics students of secondary education. Mathematics, 7(1226), 1-14. https://doi.org/10.3390/math7121226

Berenguer-Albaladejo, C. (2016). Acerca de la utilidad del aula invertida o flipped classroom. XIV Jornadas de Redes de Investigación en Docencia Universitaria. Universidad de Alicante. Alicante.

Bergmann, J., \& Sams, A. (2012). Flip your classroom: Reach every student in every class every day. Washington: International Society for Technology in Education.

Bloom, B.S., Englehart, M.D., Furst, E.J., \& Krathwohl, D.R. (1956). Taxonomy of education objectives: Cognitive domain. McGraw-Hill.

Busch, B., \& Watson, E. (2019). The science of learning: 77 studies that every teacher needs to know. New York: Routledge. https://doi.org/10.4324/9780429461545

Canizales, W., Ries, F., \& Rodríguez, C. (2020). Estilos de aprendizaje y ambiente de aula: Situaciones que anteceden a la innovación pedagógica en estudiantes de deporte. Retos, 38(February), 213-221. https://doi.org/10.47197/retos.v38i38.72791 
Castillo, M., Bracamonte, E., De la Rosa, F., Sandoval, C., \& Morales, J. (2009). Relación entre el estilo de aprendizaje de los estudiantes de primer ingreso a la Facultad de Ingeniería y su rendimiento en el curso Matemáticas Básica 1. Revista social. Available at: http://digi.usac.edu.gt/bvirtual/revista2009/resumenes/educacion/Estilos $\% 20 \mathrm{de} \% 20$ Aprendizaje.pdf (Accessed: October 2020).

Chen, S.C., Yang, S.J.H., \& Hsiao, C.C. (2015). Exploring student perceptions, learning outcome and gender differences in a flipped mathematics course. British Journal of Educational Technology, 47(6), 1096-1112. https://doi.org/10.1111/bjet.12278

Clark, R.M., \& Kaw, A.K. (2019). Benefits of adaptive lessons for pre-class preparation in a flipped numerical methods course. International Journal of Mathematical Education in Science and Technology, 51(5), 1-17. https://doi.org/10.1080/0020739X.2019.1617439

Coa, R. (2018). Aprendizaje experiencial y el Edpuzzle en la solución de problemas contextualizados de sistemas de ecuaciones de matemática básica en estudiantes de una universidad privada. Undergraduate thesis. Universidad tecnológica de Perú. Perú.

Coffield, F., Moseley, D., Hall, E., \& Ecclestone, K. (2004). Learning styles and pedagogy in post-16 learning A systematic and critical review. Learning and Skills Research Centre.

Coto, M. (2020). Descubrimiento del estilo de aprendizaje dominante de estudiantes de la carrera de tecnología en análisis de sistemas. Revista Educación, 44(1), 193-202.

Driscoll, T.F. (2012). Flipped Learning \& Democratic Education. Doctoral thesis. Teachers College, Columbia University. New York.

Dunn, R., \& Dunn, K. (1978). Teaching students thought their individual learning styles: A practical approach. Prentice Hall.

Esperanza, P., Fabian, K., \& Toto, C. (2016). Flipped Classroom Model: Effects on Performance, Attitudes and Perceptions in High School Algebra. DM Review, 9891, 85-97. https://doi.org/10.1007/9783-319-45153-4_7

Felder, R., \& Silverman, L. (1988). Estilos de aprendizaje y enseñanza. Engineering Education, 78(7), 674-681.

Fredriksen, H., Hadjerrouit, S., Monaghan, J., \& Rensaa, R. (2018). Exploring tensions in a mathematical course for engineers utilizing a flipped classroom approach. Proceedings of CERME10.

Fung, C.H. (2020). How Does Flipping Classroom Foster the STEM Education: A Case Study of the FPD Model. Technology, Knowledge and Learning, 30(14), 1945-1969. https://doi.org/10.1007/s10758-02009443-9

Gallego, D. (2004). Diagnosticar los Estilos de Aprendizaje. Conferencia del I Congreso Internacional de Estilos de Aprendizaje. Madrid.

Gardner, H. (1983). Frames of mind. The theory of multiple intelligences. New York: Basic Books.

Goleman, D. (1998). Working with emotional intelligence. Bantam Books. https://doi.org/10.1002/ltl.40619981008

Gordijn, J., Oosterhout, A., \& Dijkstra, W. (2017). Innovation Mathematics Project, Blended Education in Practice: a Case Study At Delft University of Technology. EDULEARN17 Proceedings (1, 9940-9950). https://doi.org/10.21125/edulearn.2017.0881

Gorghiu, G., Anghel, G.A., \& Ion, R.M. (2015). Students’ Perception Related to a Responsible Research and Innovation Demarche. Procedia - Social and Behavioral Sciences, 180(November), 600-605.

https://doi.org/10.1016/j.sbspro.2015.02.166 
Guerrero, S., Beal, M., Lamb, C., Sonderegger, D., \& Baumgartel, D. (2015). Flipping undergraduate finite mathematics: Findings and implications. Primus, 25(9), 814-832.

https://doi.org/10.1080/10511970.2015.1046003

Guild, P., \& Garger, S. (1998). Marching to Different Drummers. Virginia: ASCD-Association for Supervision and Curriculum Development.

Gutiérrez, M., \& García, J. (2011). Estudio comparativo de los estilos de aprendizaje del alumnado que inicia sus estudios universitarios en diversas facultades de Venezuela, México y España. Journal of Learning Styles, 4(7), Abril 2011.

Hernández, J. (2010). Análisis psicométrico del Cuestionario de Estilos de Aprendizaje Honey Alonso (CHAEA).

Hervás, R.M., \& Hernández, F. (2004). Diferentes formas de enseñar y aprender: estilos y enfoques de aprendizaje y su aplicación en contextos educativos. Available at: http://mural.uv.es/salmama/03 5225 Abstract rosa hervas.pdf (Accessed: July 2020).

Heuett, W.J. (2017). Flipping the Math Classroom for Non-Math Majors to Enrich Their Learning Experience. Primus, 27(10), 889-907. https://doi.org/10.1080/10511970.2016.1256925

Hodgson, T.R., Cunningham, A., McGee, D., Kinne, L., \& Murphy, T.J. (2017). Assessing Behavioral Engagement in Flipped and Non-Flipped Mathematics Classrooms: Teacher Abilities and Other Potential Factors. International Journal of Education in Mathematics, Science and Technology, 5(4), 248-261. https://doi.org/10.18404/ijemst.296538

Honey, P. (1988). Improve your people skills. Buckingham: Institute of Personel Management.

Hung, C.Y., Sun, J.C.Y., \& Liu, J.Y. (2018). Effects of flipped classrooms integrated with MOOCs and game-based learning on the learning motivation and outcomes of students from different backgrounds. Interactive Learning Environments, 27(8), 1028-1046. https://doi.org/10.1080/10494820.2018.1481103

Hunt, D. (1978). Student Learning styles: diagnosis and prescribing program. Reston.

Jalil, N.A., Kassim, N.I., \& Madar, A.R. (2019). Learning Based On Flipped Techniques Among The Technical Students With Different Learning Styles. International Journal of Psychosocial Rehabilitation, 23(3), 680-688. https://doi.org/10.37200/IJPR/V23I3/PR190357

Jordán, C., Magreñán, Á.A., \& Orcos, L. (2019). Considerations about flip education in the teaching of advanced mathematics. Education Sciences, 9(3), 1-10. https://doi.org/10.3390/educsci9030227

Juárez, C.L. (2014). Propiedades pscicométricas del cuestionario Honey-Alonso de estilos de aprendizaje (CHAEA) en una muestra mexicana. Revista de estilos de aprendiraje, 7(13), 136-154.

Karampa, V., \& Paraskeva, F. (2018). A motivational design of a flipped classroom on collaborative programming and STEAM. In Uden L., Liberona D., \& Ristvej, J. (Eds.), Learning Technology for Education Challenges. LTEC 2018. Communications in Computer and Information Science (870). Cham: Springer. https://doi.org/10.1007/978-3-319-95522-3_19

Khan, R.N., \& Watson, R. (2018). The flipped classroom with tutor support: An experience in a level one statistics unit. Journal of University Teaching and Learning Practice, 15(3).

Kim, J.Y. (2018). A study of students' perspectives on a flipped learning model and associations among personality, learning styles and satisfaction. Innovations in Education and Teaching International, 55(3), 314-324. https://doi.org/10.1080/14703297.2017.1286998

Kirvan, R., Rakes, C., \& Zamora, R. (2015). Flipping an Algebra Classroom: Analyzing, Modeling, and Solving Systems of Linear Equations. Computers in the Schools, 32, 201-223.

http://doi.org/10.1080/07380569.2015.1093902 
Kolb, D. (1976). The Learning Style Inventory: Tecbnical Manual. McBer.

Kumar, K., Chang, C., \& Chang, C. (2015). International Forum of Educational Technology \& Society The Impact of the Flipped Classroom on Mathematics Concept Learning in High School. Educational Technology \& Society, 19(3), 134-142.

Leatherman, J.L., \& Cleveland, L.M. (2018). Student exam performance in flipped classroom sections is similar to that in active learning sections, and satisfaction with the flipped classroom hinges on attitudes toward learning from videos. Journal of Biological Education, 54(3), 328-344.

https://doi.org/10.1080/00219266.2019.1575266

Li, Y.B., Zheng, W.Z., \& Yang, F. (2017). Cooperation learning of flip teaching style on the MBA mathematics education efficiency. Eurasia Journal of Mathematics, Science and Technology Education, 13(10), 6963-6972. https://doi.org/10.12973/ejmste/76878

Lopes, A.P., \& Soares, F. (2017). What Do Students of a Higher Education Institution Think About Flipped Learning. EDULEARN17 Proceedings, 1(July), 2759-2766.

https://doi.org/10.21125/edulearn.2017.1582

Lozano, A. (2000). Estilos de Aprendiraje y Enseñanza. Un panorama de la estilística educativa. Trillas.

Martin, D., \& Santiago, R. (2017). Evaluation of a Study on Flipped Learning and the Use of Digital Tools in Higher Education: Teacher Training. Pedagogika, 8(2), 60-85.

Martín, D., \& Santiago, R. (2015). ¿Es el flipped classroom un modelo pedagógico eficaz? Comunicación y Pedagogia: Nuevas Tecnologias y Recursos Didácticos, 285, 29-35.

Maureira, F. (2013). Validez y confiabilidad del CHEA en estudiantes de educación física. Educación Física Chile, 271, 8-15.

Muir, T. (2020). Self-determination theory and the flipped classroom: A case study of a senior secondary mathematics class. Mathematics Education Research Journal. https://doi.org/10.1007/s13394-020-00320-3

Ni, M., Kwok, L., Zhen, L., Xie, Y., Long, H., Zheng, X., et al. (2015). Preface. Lecture Notes in Computer Science (Including Subseries Lecture Notes in Artificial Intelligence and Lecture Notes in Bioinformatics), 9167, 243-254.

Nihlawi, R., El-Baz, H., \& Gunn, C. (2017). Looking into the Impact of Flipped Learning Pedagogy on Students' Perceived Learning Experience in Undergraduate Mathematics Courses. ICERI2017 Proceedings (5809-5819). Sevilla, España. https://doi.org/10.21125/iceri.2017.1521

Novak, J., Kensington-Miller, B., \& Evans, T. (2016). Flip or flop? Students' perspectives of a flipped lecture in mathematics. International Journal of Mathematical Education in Science and Technology, 48(5), 647-658. https://doi.org/10.1080/0020739X.2016.1267810

Padierna-Luna, J.L., Oseguera-Rodríguez, J., \& Gudiño-Hernández, N. (2009). Socioacademic factors, style of learning, intellectual level and their relationship with the previous academic yield of medical students. Educación Médica, 12(2), 91-102. https://doi.org/10.33588/fem.122.517

Parslow, G.R. (2005). Multimedia in Biochemistry and Molecular Biology Education Commentary: Critical Thinking. Biochemistry and moleculary biology education, 33(5), 371.

https://doi.org/10.1002/bmb.2005.49403305371

Pashler, H., Mcdaniel, M., Rohrer, D., \& Bjork, R. (2008). Learning styles: Concepts and evidence. Psychological Science in the Public Interest, 9(3), 105-119. https://doi.org/10.1111/j.1539-6053.2009.01038.x 
Prieto, A. (2017). Profesor 3.0: Flipped classroom ¿Cuáles son sus ventajas? ¿Cuál es su origen y su evolución posterior? ¿Por qué no es una moda más? ¿Por qué mejora el aprendizaje? ¿Por qué deberías leer sobre este modelo en este verano? Available at: http://profesor3punto0.blogspot.com/2016/07/flippedclassroom-cuales-son-sus 7.html (Accessed: July 2020).

Rayner, S., \& Riding, R.J. (1997). Towards a categorizations of cognitive styles and learning. Educational Psychology, 17. https://doi.org/10.1080/0144341970170101

Riener, C., \& Willingham, D. (2010). The Myth of Learning Styles. Change: The Magazine of Higher Learning, 42(5), 32-35. https://doi.org/10.1080/00091383.2010.503139

Rivero, A. (2019). Impact of three teaching models in university general botany courses on the academic results of students. Formacion Universitaria, 12(3), 67-80. https://doi.org/10.4067/S0718-50062019000300067

Salas-Perea, R., \& Salas-Mainegra, A. (2014). La educación en el trabajo y el individuo como principal recurso para el aprendizaje. Edumecentro, 6(1), 1-13.

Sánchez-Compaña, M.T., \& Sánchez-Cruzado, C. (2019). Design and Validation of a Questionnaire In Order to Assess the Adaptation of Educational Practices to the Flipped Learning Model. Aloma, 37(2), 25-33. https://doi.org/10.51698/aloma.2019.37.2.25-33

Santiago, R., \& Bergmann, J. (2018). Aprender al revés. Ediciones Paidós.

Song, Y., \& Kapur, M. (2017). How to Flip the Classroom - "Productive Failure or Traditional Flipped Classroom ” Pedagogical Design? Journal of Educational Technology \& Society, 20(1), 292-305.

Steen-Utheim, A.T., \& Foldnes, N. (2018). A qualitative investigation of student engagement in a flipped classroom. Teaching in Higher Education, 23(3), 307-324. https://doi.org/10.1080/13562517.2017.1379481

Strelan, P., Osborn, A., \& Palmer, E. (2020). The flipped classroom: A meta-analysis of effects on student performance across disciplines and education levels. Educational Research Review, 30, 100314.

https://doi.org/10.1016/j.edurev.2020.100314

Stroh, H.R., \& Sink, C.A. (2002). Applying APA’s Learner-Centered Principles to School-Based Group Counseling. Professional School Counseling, 6(1), 71-78.

Sun, Z., Xie, K., \& Anderman, L.H. (2017). The role of self-regulated learning in students' success in flipped undergraduate math courses. Internet and Higher Education, 36, 41-53.

https://doi.org/10.1016/j.iheduc.2017.09.003

Talbert, R. (2012). Inverted Classroom. Colleagues, 9(1).

Talbert, R. (2017). Flipped Learning: Aguide for higber education faculty. Sterling, Virginia: Stylus Publishing.

Toor, A., \& Mgombelo, J. (2018). Math centers: A pedagogical tool for student engagement in intermediate math class. Available at: https://hal.archives-ouvertes.fr/hal-01949020 (Accessed: July 2020).

Tourón, J., \& Santiago, R. (2015). El modelo Flipped Learning y el desarrollo del talento en la escuela. Revista de Educacion, 368, 33-65.

Triantafyllou, E., \& Timcenko, O. (2014). Introducing a flipped classroom for a statistics course: A case study. Proceedings of the 25th International Conference on European Association for Education in Electrical and Information Engineering, EAEEIE 2014 (5-8). https://doi.org/10.1109/EAEEIE.2014.6879373

Wei, X., Cheng, I.L., Chen, N.S., Yang, X., Liu, Y., Dong, et al. (2020). Effect of the flipped classroom on the mathematics performance of middle school students. Educational Technology Research and Development, 68, 1461-1484. https://doi.org/10.1007/s11423-020-09752-x 
Weinhandl, R., Lavicza, Z., Hohenwarter, M., \& Schallert, S. (2020). Enhancing flipped mathematics education by utilising geogebra. International Journal of Education in Mathematics, Science and Technology, 8(1), 1-5. https://doi.org/10.46328/ijemst.v811.832

Westby, C. (2019). The Myth of Learning Styles. Word of Mouth, 31(2), 4-7.

https://doi.org/10.1177/1048395019879966a

Ziegelmeier, L.B., \& Topaz, C.M. (2015). Flipped calculus: A study of student performance and perceptions. Primus, 25(9), 847-860. https://doi.org/10.1080/10511970.2015.1031305

\author{
Published by OmniaScience (www.omniascience.com) \\ Journal of Technology and Science Education, 2021 (www.jotse.org)
}

\title{
(c) $(1)(8)$
}

Article's contents are provided on an Attribution-Non Commercial 4.0 Creative commons International License. Readers are allowed to copy, distribute and communicate article's contents, provided the author's and JOTSE journal's names are included. It must not be used for commercial purposes. To see the complete licence contents, please visit https://creativecommons.org/licenses/by-nc/4.0/. 